\title{
Kebijakan Pre-Merger Notification Badan Usaha Sebagai Penegakan Hukum di Era Revolusi Industri 4.0
}

\author{
Farid Ibrahim Suhandi \\ Mahasiswa Fakultas Hukum, Universitas Diponegoro \\ JI. Prof. Soedarto, Tembalang, Kec. Tembalang, Kota Semarang, Jawa Tengah 50275
}

Surel: faridsuhandi@gmail.com

\begin{abstract}
ABSTRAK
Konsekuensi dari adanya dinamika globalisasi menimbulkan suatu fenomena apriori yang dinamakan dengan Revolusi Industri 4.0 sehingga hal ini mejadi tantangan bagi Komisi Pengawasan Persaingan Usaha (KPPU) untuk dapat melindungi keadaan pasar yang berkembang sedinamika mungkin. Melalui hal tersebut maka kewenangan daripada KPPU perlu untuk dioptimalisasikan demi menyesuaikan dinamika pasar. Pelaksanaan merger suatu perusahaan menjadi keadaan yang berpotensi menimbulkan suatu bentuk persaingan usaha yang tidak sehat. Hal ini tentu menjadi kewenangan KPPU untuk dapat memberikan pengawasan dan penilaian akan hal tersebut, namun dengan masih berlakunya rezim pasca-notifikasi merger membuat terjadinya kemungkinan adanya pembatalan suatu merger yang berdampak pada kerugian yang diderita perusahaaan. Oleh karena itu, diperlukan perubahan rezim menjadi pra-notifikasi merger yang telah melalui beberapa pertimbangan yang diperlukan. Dengan demikian, maka diharapkan KPPU mampu menjadi pelindung utama akan terciptanya keadaan pasar yang adil dan kondusif.
\end{abstract}

\author{
RIWAYAT ARTIKEL \\ Article History \\ Diterima : 26 Agustus 2019 \\ Dipublikasi : 25 November 2019
}

\author{
KATA KUNCI \\ Keywords \\ Komisi Pengawasan Persaingan \\ Usaha, Pra-Notifikasi Merger, \\ Revolusi Industri 4.0
}

\section{HOW TO CITE (saran perujukan):}

Suhandi, F.I. (2019). "Kebijakan Pre-Merger Notification Badan Usaha Sebagai Penegakan Hukum di Era Revolusi Industri 4.0", Lex Scientia Law Review. Volume 3 Nomor 2, November, hlm. 129-142 


\section{PENDAHULUAN}

Globalisasi merupakan suatu fenomena perkembangan yang terus berputar dan turut memaksa tiap negara untuk dapat menyesuaikan diri agar mampu bersaing dengan cepatnya perkembangan peradaban tersebut. Terutama pada perkembangan era saat ini, yaitu mulai memasuki pada era Revolusi Industri 4.0, yang mana merupakan ambang revolusi modern yang secara holistik akan mengubah sistem kerja dari bisnis, ekonomi, dan permasalahan sosial pada tingkat nasional hingga internasional. Namun yang menjadi titik fokus utama dalam Revolusi Industri 4.0, yaitu pada peningkatan efisiensi ekonomi yang tinggi, dimana perubahan fundamental tersebut mampu mengikis rantai perekonomian di Indonesia menjadi lebih efisien. Hal tersebut tentu dapat berdampak buruk bila tidak dipersiapkan sejak dini, sehingga dengan begitu pemerintah harus mampu untuk menyesuaikan diri dengan keberadaan Revolusi Industri 4.0 tersebut, karena jika tidak, maka kekuatan perekonomian negara akan mengalami kelumpuhan dan kesulitan untuk menyaingi laju perekonomian negara lain.

Fenomena Revolusi Industri 4.0 merupakan kelanjutan dari tahap-tahap revolusi industri yang pernah terjadi. Revolusi industri pertama terjadi di Inggris pada tahun 1784 di mana penemuan mesin uap dan mekanisasi mulai menggantikan pekerjaan manusia. Revolusi yang kedua terjadi pada akhir abad ke-19 di mana mesin-mesin produksi yang ditenagai oleh listrik digunakan untuk kegiatan produksi secara masal. Penggunaan teknologi komputer untuk otomasi manufaktur mulai tahun 1970 menjadi tanda revolusi industri ketiga. Saat ini, perkembangan yang pesat dari teknologi sensor, interkoneksi, dan analisis data memunculkan gagasan untuk mengintegrasikan seluruh teknologi tersebut ke dalam berbagai bidang industri. Gagasan inilah yang diprediksi akan menjadi revolusi industri yang berikutnya. Sehingga Revolusi Industri 4.0 merupakan fenomena yang unik jika dibandingkan dengan tiga revolusi industri yang mendahuluinya. Revolusi Industri 4.0 diumumkan secara apriori karena peristiwa nyatanya belum terjadi dan masih dalam bentuk gagasan (R Drath \& Horch, 2014: 56-58). Fenomena tersebut diyakini mampu memberikan banyak manfaat yang diantaranya mengenai perbaikan kecepatan fleksibilitas produksi, peningkatan layanan kepada pelanggan, dan peningkatan pendapatan kolektif (Lasi et.al, Business \& Information Systems Engineering, 2014: 239). Melihat hal tersebut, maka keberadaan Revolusi Industri 4.0 menjadi suatu yang harus diwaspadai oleh negara selaku pemangku kebijakan, karena dikhawatirkan dapat menjadi ancaman bagi stabilitas perekonomian negara.

Dampak dari adanya revolusi industri turut menimbulkan masalah terkhususnya pada bentuk persaingan usaha, yang mana para pengusaha tentu akan memanfaatkan fenomena tersebut sebagai batu loncatan untuk dapat menguasai pasar perdagangan. Hal ini tentu dapat menimbulkan adanya persaingan tidak sehat 
dalam keberlangsungannya, padahal jika melihat regulasi yang ada saat ini yaitu Undang-Undang Nomor 5 Tahun 1999 tentang Larangan Praktek Monopoli dan Persaingan Usaha Tidak Sehat.

Larangan praktek monopoli dan persaingan usaha tidak sehat belum mampu untuk dapat mengakomodir bentuk-bentuk permasalahan yang nantiya ditimbulkan dari Revolusi Industri 4.0 tersebut, yang mana dapat meliputi beberapa poin-poin permasalahan yang menjadi titik fokus dalam penulisan ini, yaitu: pertama, adanya kekhawatiran akan menimbulkan reaksi pasar yang berlebihan dari adanya perkembangan kondisi tersebut, sehingga perusahaan-perusahaan yang tidak mampu menyesuaikan diri akan secara reaksioner mengalami penurunan investasi. Kedua, dalam perkembangannya akan banyak cara yang dilakukan oleh suatu perusahaan dalam mengoptimalisasikan sumber daya yang ada seperti modal, teknologi managemen, dan lain-lainnya guna memperoleh sinergisme baru dalam melakukan kegiatan usaha yang mengacu pada efisiensi dan produktifitas, salah satu cara tersebut adalah dengan jalan merger atau penggabungan dua badan usaha atau lebih (Normin S, 1995: 27). Mengacu pada Undang-Undang Nomor 5 Tahun 1999 tentang Larangan Praktek Monopoli dan Persaingan Usaha Tidak Sehat dalam Pasal 28 dan Pasal 29, menegaskan bahwa keberadaan merger suatu perusahaan dapat berpotensi untuk terjadinya praktik persaingan usaha tidak sehat, oleh karena itu jika dikaitkan dengan Revolusi Industri 4.0 maka angka untuk timbulnya keinginan perusahaan untuk melakukan merger diprediksikan akan lebih tinggi pada angka biasanya, sehingga sebagai konsekuensi logis dari hal tersebut dapat berdampak pada meningkatnya potensi praktik persaingan tidak sehat.

Ketiga, permasalahan yang timbul dari pasca penggabungan suatu perusahaan (merger) yakni berpotensi timbulnya laporan yang baru terindikasi adanya praktik persaingan tidak sehat, sehingga berakibat pada pembubaran perusahaan gabungan atas merger yang telah dilakukan tersebut, karena pada praktiknya peranan Komisi Pengawasan Persaingan Usaha (KPPU) mengenai merger atau penggabungan suatu perusahaan hanya sebagai penasehat dan pemberian notifikasi yang tidak menjadi suatu kewajiban bagi perusahaan. Namun, bilamana pasca merger diindikasikan terdapat unsur persaingan tidak sehat, maka KPPU dapat memberikan sanksi untuk membatalkan merger tersebut. Hal ini tentu bertentangan dengan efektifitas dan efisiensi penegakan hukum pada ranah persaingan usaha khususnya KPPU selaku komisi negara yang berwenang menjadi pengawas akan hal tersebut, sehingga secara tidak langsung akan menghambat berkembangnya proses perekonomian pada era Revolusi Industri 4.0 yang akan datang.

Perlu dilihat kembali bahwa nilai aktivitas merger dan akuisisi pada 2016 tumbuh 25,78 persen menjadi US\$ 1,98 miliar atau setara Rp26,28 triliun dengan kurs Rp13.300 per dolar Amerika. Nilai tersebut terdiri atas merger dan akuisisi yang berasal dari investasi domestik senilai US\$ 1,08 miliar dan dari luar negeri sebesar 
US\$ 893 juta. Menurut Laporan Perekonomian Indonesesia Bank Indonesia 2016, nilai merger dan akuisisi domestik pada 2016 melonjak 45,3 persen dari tahun sebelumnya, yakni hanya US\$ 196 juta. Sementara merger dan akuisisi dari dan ke luar negeri pada 2016 justru mengalami penurunan 35 persen dari tahun sebelumnya, yaitu senilai US\$ 1,38 miliar (https://databoks.katadata.co.id/ datapublish/2017/05/15/merger-dan-akuisisi-indonesia-2016-tumbuh-26 diakses pada 25 Maret 2019). Hingga sejak tahun 2010 banyak pelaku usaha di berbagai sektor yang melaporkan aksi korporasinya kepada KPPU, dimana jumlah perbandingan notifikasi merger tersebut yakni 68 pada 2016 dan 90 pada 2017, yang artinya bahwa terjadi peningkatan signifikan terjadi pada tahun 2017 yang menjadi peningkatan terbanyak sejak Peraturan Pemerintah Nomor 57 Tahun 2010 lahir dan menjadi aturan pelaksanaan UU Nomor 5 Tahun 1999 (Laporan Pengawasan Persaingan Usaha, 2017: 8).

Tingginya angka tersebut tentu menjadi tantangan tersendiri bagi KPPU untuk melakukan pengawasan yang optimal dalam penegakan hukum terhadap persaingan usaha tidak sehat sebagai kemungkinan dampak yang ditimbulkan dari proses merger suatu perusahaan. Keempat, masalah lainnya yang perlu dikaji yaitu diperlukannya pengaturan mengenai waktu dan penerapan ambang batas (threshold) aset yang dilaporkan dalam proses merger. Karena pasalnya KPPU harus melakukan penilaian paling lama 25 hari kerja terkait rencana merger atau akuisisi, serta penerapan threshold aset yang dilaporkan masih bernilai Rp2,5 triliun sampai Rp200 triliun untuk perbankan, besar kemungkinan KPPU akan kebanjiran permohonan rencana merger atau akuisisi untuk kedepannya. Sehingga diperlukan pengkajian yang komprehensif melalui perhitungan yang mampu menyesuaikan perkembangan praktik bisnis dan perekonomian pasar di Indonesia, sehingga pengaturan ini mampu memberikan jaminan akan kepastian hukum yang adil, efektif dan efisien.

\section{Rumusan Masalah}

Berdasarkan penjabaran latar belakang tersebut, maka dapat ditarik sejumlah rumusan masalah sebagai titik fokus dalam melakukan pengkajian yaitu, bagaimanakah sistem notifikasi merger badan usaha yang ada di Indonesia saat ini? dan bagaimanakah rekonstruksi sistem notifikasi merger badan usaha sebagai penegakan hukum di era Revolusi Industri 4.0?, melalui rumusan tersebut maka diajukannya tulisan ini sebagai penjabaran solusi yang sistematis dan komprehensi untuk menjawab permasalahan yang mungkin dapat terjadi sebagai ancaman bagi stabilitas perekonomian negara pada era Revolusi Industri 4.0 mendatang. 


\section{Metode Penulisan}

Jenis penelitian dalam karya artikel ilmiah ini adalah penelitian hukum yuridis normatif diperkuat menggunakan pendekatan yang lazim digunakan dalam penelitian hukum (Legal Research), antara lain: pendekatan undang- undang (Statute Approach), dan pendekatan konseptual (Conseptual Approach). Penelitian hukum melalui pendekatan peraturan perundang-undangan (Statute Approach) dilakukan dengan menelaah semua undang-undang dan regulasi yang bersangkut paut dengan isu hukum yang sedang ditangani. Pendekatan konseptual (Conseptual Approach) dengan menganalisis dan mengkritisi terhadap pelaksanaan pengawasan merger yang telah dilaksanakan oleh KPPU hingga saat ini. Penelitian yang dipilih adalah berupa penelitian kualitatif, dimana wujud dari data penelitian adalah informasi yang berupa kata-kata atau disebut data kualitatif. Jenis penelitian ini tidak menggunakan angka-angka untuk keperluan analisis kuantitatif statistik. Berdasarkan sumber penelitian menggunakan data sekunder.

\section{PEMBAHASAN}

\section{A. Pengaturan dan Pelaksanaan Sistem Notifikasi Merger Badan Usaha di Indonesia Saat Ini}

Prinsip perekonomian Indonesia secara tegas tercantum dalam konstitusi yang mengataskan pelaksanaan perekonomian pada prinsip kebersamaan, efisiensi berkeadilan, berkelanjutan, berwawasan lingkungan, kemandirian, serta dengan menjaga keseimbangan kemajuan dan kesatuan ekonomi nasional, perlu didukung oleh kelembagaan perekonomian yang kokoh dalam rangka mewujudkan kesejahteraan masyarakat. Sehingga negara memiliki keterlibatan besar dalam rangka menata perekonomian hingga pada sektor perekonomian swasta. Oleh karena itu sebagai bentuk peningkatan pembangunan perekonomian nasional dan memberikan perlindungan dalam persaingan dunia usaha dalam menghadapi perkembangan perekonomian dunia di era globalisasi, terutama dalam menghadapi adanya Revolusi Industri 4.0, maka keterlibatan negara perlu didukung oleh suatu pembaharuan yang sistematis sehingga dapat dapat menjamin terselenggaranya iklim dunia usaha yang kondusif.

Pada perkembangannya, peran badan usaha khususnya sektor swasta kerap kali menjadi sarana peningkatan perekonomian yang efektif dan efisien di tiap negara, karena dianggap mampu secara cepat untuk dapat berkembang mengikuti dinamika perekonomian pada era globalisasi. Namun, demi meningkatkan efisiensi, tidak jarang untuk beberapa badan usaha tertarik untuk melakukan merger atau penggabungan badan usaha dengan badan usaha lain yang dinilai dapat menghasilkan value lebih baik untuk prospek kepentingan kedepannya. Hal ini terkadang dapat menciptakan kemungkinan untuk terjadinya monopoli atau persaingan usaha tidak sehat, oleh karena itu kepentingan setiap badan udaha tetap 
harus dilindungi dan diawasi oleh negara agar dinamika perekonomian dapat lebih kondusif.

Sebagai konsekuensi dari negara kesejahteraan atau welfare state, maka untuk mencegah terjadinya persaingan yang tidak sehat akibat menumpuknya kekuatan ekonomi pada sekelompok kecil pelaku ekonomi serta sejauh mungkin mencegah monopoli dan monopsoni dalam segala bentuknya yang merugikan masyarakat, maka harus diatur tentang persyaratan dan tata cara merger sebab di dalam merger akan terjadi posisi dominan yang pada akhirnya dapat menimbulkan praktik monopoli. Namun demikian, di sisi lain merger bertujuan untuk memperluas jaringan usaha dan meningkatkan kinerja perusahaan, serta salah satu metode untuk melakukan restrukturisasi perusahaan. Merger atau penggabungan merupakan perbuatan hukum yang dilakukan oleh satu badan usaha dengan badan usaha lainnya untuk menggabungkan diri dan bersama-sama menjalankan usahanya. Merger dilaksanakan dengan maksud agar dapat memberikan keefektifan dalam berusaha serta membantu usaha kecil yang sedang membutuhkan dana segar agar usahanya tetap berjalan dengan baik. Namun dalam praktiknya, banyak transaksi merger yang dilakukan oleh perusahaan didorong oleh motif untuk meningkatkan kekuatan pasar (market power) di pasar bersangkutan, baik peningkatan kekuatan pasar pada satu perusahaan maupun peningkatan kekuatan pasar pada sekelompok perusahaan yang independen (Sudjana, Jurnal Hukum POSITUM, Vol. 1, No. 1, 2016:106). Oleh karena itu, hukum persaingan usaha memiliki peran yang penting dalam mengatur dan menstabilkan perkembangan perekonomian di Indonesia.

Hukum persaingan usaha merupakan salah satu perangkat hukum penting dalam ekonomi pasar (market economy). Melalui hukum persaingan usaha, pemerintah berupaya melindungi persaingan yang sehat antar pelaku usaha di dalam pasar. Khemani, menjelaskan bahwa persaingan yang sehat akan memaksa pelaku usaha menjadi lebih efisien dan menawarkan lebih banyak pilihan produk barang dan jasa dengan harga yang lebih murah. Pengalaman di banyak negara industri baru di Asia Timur terutama Korea Selatan dan Taiwan menunjukkan bahwa persaingan usaha yang sehat memaksa pelaku usaha untuk meningkatkan efisiensi dan mutu produk serta melakukan inovasi. Persaingan yang terjadi dalam dunia usaha telah mendorong perusahaan-perusahaan manufaktur di negara tersebut untuk meningkatkan daya saing dengan melakukan investasi lebih besar dalam teknologi. Sebaliknya, perusahaan yang tidak efisien dan tidak kompetitif, serta tidak responsif terhadap kebutuhan konsumen, akan dipaksa keluar dari persaingan (Wie, 2004: 173). Pada perkembangannya, pemberlakuan merger terjadi dalam 3 (tiga) macam bentuk, yang secara umum dapat dijabarkan sebagai berikut (Lubis et. al., 2009: 191) 1. Merger horizontal, Merger jenis ini terjadi apabila dua perusahaan yang memiliki lini usaha yang sama bergabung atau apabila perusahaan-perusahaan yang bersaing di industri yang sama melakukan merger. 
2. Merger vertikal, Merger jenis ini terjadi apabila merger tersebut melibatkan suatu tahapan operasional produksi yang berbeda yang saling terkait satu sama lainnya, mulai dari hulu hingga ke hilir. Merger vertikal dapat terjadi dalam 2 (dua) jenis yaitu secara upstream dan downstream.

3. Merger konglomerat, Merger konglomerat terjadi apabila 2 (dua) perusahaan yang tidak memiliki lini usaha yang sama bergabung. Dengan kata lain, merger konglomerat terjadi antara perusahaan perusahaan yang tidak bersaing dan tidak memiliki hubungan penjual-pembeli.

Melihat dari ketiga macam jenis merger, pada prakteknya merger horizontal dapat dikatakan sebagai jenis merger yang menjadi perhatian badan otoritas semacam KPPU diberbagai negara. merger jenis ini terjadi antara dua perusahaan yang bersaing di dalam pasar untuk produk dan/atau jasa yang sama. Melalui mekanisme merger tersebut, yang mana dengan dua entitas yang saling bersaing tersebut menjadi sebuah entitas tunggal yang tentunya akan lebih mendominasi pasar pasca tereleminasinya entitas lain (hal serupa dalam akuisisi karena satu entitas menjadi tunduk pada entitas lainnya dalam proses keputusan bisnis) (Jones dan Surfin, 2011: 857).

Meski dampak yang diberikan tak senyata merger horizontal, merger vertikal juga tak kalah mendapatkan perhatian dari otoritas persaingan usaha. Merger vertikal akan berakibat dikuasainya sebuah rantai produksi oleh perusahaan yang melakukan merger tersebut. Merger vertikal sangat mungkin mengakibatkan tertutupnya kesempatan pelaku usaha lain untuk mendapatkan persediaan yang memadai karena sumber dari persediaan tersebut telah dimerger dengan pelaku usaha kompetitor. Sebagai contoh, merger yang terjadi antara sebuah perusahaan di rantai pabrikan dan perusahaan lainnya yang menyediakan komponen tertentu untuk perusahaan pabrikan tersebut akan berdampak pada hilangnya kesempatan perusahaan pabrikan kompetitor untuk mendapatkan kesempatan yang sama dalam memperoleh komponen tersebut. Merger vertikal juga sangat mungkin meningkatkan peluang terjadinya transparansi harga atau memfasilitasi kolusi antara perusahaanperusahaan yang ada di pasar (Jones dan Surfin, 2011: 858).

Perlunya merger diatur secara tersendiri dalam hukum persaingan usaha adalah berkenaan dengan dampak negatif yang mungkin muncul pasca berlangsungnya sebuah merger. Dampak negatif merger terhadap iklim persaingan sangat mungkin terjadi ketika merger tersebut membuat terjadinya kondisi dominan sehingga memiliki kecenderungan untuk menciptakan distorsi pasar dengan jalan menaikkan harga produk dan/atau jasa dari perusahaan yang bersangkutan. Hal ini terjadi karena tidak adanya tekanan persaingan dari para pesaingnya. Efek negatif juga timbul dari suatu merger antara perusahaan yang produknya memiliki pembeda dengan produk lain (differentiated product) yang beredar di pasar. Hal ini karena, apabila terjadi kenaikan harga atas produk tersebut, konsumen yang bersangkutan tidak dapat mengganti dan mengalihkan barang tersebut kepada produsen yang lain 
karena tidak ada barang pengganti yang dapat ditemukan di dalam pasar (Saputro, 2012: 12). Merger juga dapat menghadirkan sikap inefisien pada perusahaan pasca berlangsungnya proses merger tersebut. Hal ini lahir dari perusahaan yang berada dalam posisi dominan sehingga merasa tidak perlu menciptakan inovasi baru. Dalam kondisi demikian, konsumen adalah pihak yang paling dirugikan karena dipaksa untuk membayar harga yang tidak seharusnya atau melakukan pembayaran yang tidak sebanding antara nilai barang dan harga (Dunnet, 1998: 51).

Peran yang dilakukan oleh KPPU dalam mengawasi adanya praktik merger suatu badan usaha saat ini dirasa kurang optimal dan keliru, dikarenakan mekanisme pengawasan tersebut lebih bersifat pada bentuk notifikasi pascamerger yang mengatur bahwa sebuah merger selambat-lambatnya dilaporkan 30 (tiga puluh) hari sejak tanggal merger tersebut berlaku efektif. Sebagai konsekuensi logis dari pemberlakuan notifikasi pasca-merger, dapat menciptakan kemungkinan bahwa akan terjadinya keadaan dimana KPPU melakukan pembatalan merger terhadap pelaku-pelaku usaha yang telah melakukan merger karena dinilai bertentangan dengan semangat persaingan usaha yang sehat. Dengan terjadinya kemungkinan tersebut, tentu sangat merugikan para pelaku usaha dan tidak sejalan dengan semangat untuk menciptakan percepatan pembangunan untuk dapat bertarung dalam revolusi industri yang akan datang. Oleh karena itu pengaturan mengenai notifikasi merger sudah sepatutnya untuk diperbaharui. Hal ini sejalan dengan perkembangan yurisdiksi hukum persaingan usaha di negara-negara lain, yang mana telah banyak memberlakukan notifikasi pra-merger ataupun pra-merger, karena dinilai dapat lebih menguntungkan kedua belah pihak (negara maupun pelaku usaha).

Walaupun pada regulasi saat ini, tepatnya pada Peraturan Pemerintah Nomor 57 tahun 2010 telah membuka ruang bagi pelaku usaha untuk melakukan pelaporan pre-notifikasi dalam bentuk konsultasi. Namun hal ini tidaklah menghapus kewajiban pelaku usaha untuk tetap melaporkan setelah tindakan merger, akuisisi, maupun konsolidasi selesai dan efektif secara yuridis. Dari 85 laporan yang disampaikan pelaku usaha sampai dengan Desember 2017, KPPU menerima satu laporan berupa konsultasi dalam industri manufaktur (Laporan Pengawasan Persaingan Usaha, 2017: 8). Hal ini terjadi karena, rezim yang saat ini diwajibkan adalah postmerger notification, sehingga pelaku usaha kerap lebih menggunakan postmerger notification ketimbang pre-merger notification, karena sifatnya yang masih berupa konsultasi dan tidak menghapus adanya kewajiban untuk melakukan laporan pasca merger. Kekhawatiran berbagai kalangan untuk diterapkannya pre-merger, yakni agar KPPU tidak menjadi badan atau lembaga perijinan yang dapat menghambat perkembangan dunia usaha. Padahal hal tersebut merupakan konsekuensi dari negara kesejahteraan welfare state yang mana menjadi suatu hal yang wajar bila negara memberikan kewajiban berupa perijinan agar pelaksanaan suatu usaha tidak 
merugikan pelaku usaha kecil dan merugikan langsung kepada masyarakat selaku konsumen.

\section{B. Rekonstruksi Sistem Notifikasi Merger Badan Usaha Dalam Penegakan Hukum di Era Revolusi Industri 4.0}

Pengenalan rezim kontrol pra-merger telah terlebih dahulu dilaksanakan di Amerika Serikat dan kemudian di Eropa dan negara-negara lain menciptakan kerangka kerja yang harus dipertimbangkan perusahaan ketika mereka mempertimbangkan merger, akuisisi, atau usaha patungan. Pengawasan harus diterapkan untuk menentukan apakah transaksi yang diusulkan harus diberitahukan kepada otoritas persaingan yang relevan. Untuk yurisdiksi di mana pemberitahuan itu wajib dan apabila terjadi kewajiban yang macet, maka transaksi harus ditangguhkan sampai otorisasi diberikan. Praktek di banyak negara telah memiliki fitur-fitur tertentu yang membuat notifikasi wajib bahkan jika transaksi tidak memiliki dampak yang terlihat pada wilayah tertentu keberadaan tren ini berkontribusi pada meningkatnya biaya transaksi (International Chamber of Commerce, 2015: 5). Melihat hal tersebut, sudah menjadi hal yang wajar untuk dilakukan perubahan rezim dari post-merger notification menjadi pre-merger notification yang dilengkapi dengan persyaratan yang bertahap.

Melihat pertimbangan tersebut maka penulis menyarankan untuk dilakukan premerger notification yang dapat diartikan sebagai bentuk kewajiban bagi pelaku usaha sebelum melakukan penggabungan badan usaha atau merger untuk melakukan konsultasi atas penggabungan atau merger yang akan dilakukan secara lisan maupun tertulis dan diwajibkan untuk memberitahukan kepada KPPU mengenai hal-hal yang diperlukan untuk mendapatkan penilaian, sehingga wajib memperoleh persetujuan KPPU sebelum dilaksanakannya proses merger. Hal ini dilakukan agar tidak terjadi bentuk persaingan usaha tidak sehat setelah dilakukannya penggabungan atau merger badan usaha tersebut. Sehingga setelah dilakukannya merger pelaku usaha tersebut tidak perlu khawatir akan adanya kemungkinan pembatalan merger oleh KPPU.

Sebagai konsekuensi dari hal tersebut, maka diperlukan pengkajian ulang terhadap ambang batas wajib untuk melakukan pelaporan. Hal ini perlu untuk ditingkatkan karena akan berdampak pada menurunnya kinerja dari KPPU melihat diberlakukannya pre-merger notification yang artinya akan ada kenaikan yang cukup besar terhadap permohonan pemberitahuan merger suatu badan usaha. Ambang batas yang semula hanya dengan nilai aset $\mathrm{Rp} 2,5$ triliun dan/atau nilai penjualan Rp5 triliun. Sementara itu, untuk pelaku di bidang perbankan wajib menyampaikan pemberitahuan tertulis jika aset gabungan melebih Rp20 triliun seyogyanya perlu untuk ditingkatkan dengan mengikuti rambu-rambu sebagaimana direkomendasikan oleh International Chamber of Commerce (ICC) yakni bahwa harmonisasi ambang batas 
di atas merger perlu ditinjau dengan mempertahankan hanya ambang yang dinyatakan secara obyektif dan omset terukur atau tingkat aset yang dicapai oleh usaha untuk merger, dan menghilangkan penggunaan ambang batas pangsa pasar (International Chamber of Commerce, 2015: 5). Dengan demikian, ambang batas merger tidak boleh tergantung kegiatan kelompok penjual atau entitas penjual tetapi harus berfokus pada kegiatan target.

Sebagai konsekuensi dari adanya pre-merger notification, maka diperlukan sarana bagi para pelaku usaha untuk mendapatkan kepastian hukum. Salah satunya melalui tinjauan merger, yang mana memiliki peran penting bagi otoritas persaingan untuk mencegah penciptaan melalui merger dan akuisisi kekuatan pasar yang tinggi atau struktur pasar yang mendorong terkoordinasi interaksi pasar. Selain itu, keputusan merger adalah sarana untuk meningkatkan profil otoritas persaingan. Meskipun undang-undang mengatur untuk tinjauan merger, ketentuan tersebut masih menunggu peraturan pemerintah, sebagai syarat untuk aplikasi dan validitas hukum. Ada resistensi kuat dari beberapa anggota pemerintah. Meskipun diperlakukan sebagai prioritas tinggi dalam KPPU, namun inisiatif organisasi dalam empat atau lima tahun terakhir tidak membuahkan hasil. Namun, sementara menunggu peraturan ini, KPPU dilaporkan akan menyelesaikan pedoman tinjauan merger. Tinjauan merger memakan sumber daya (Kebijakan Kompetisi dan Kelompok Kerja Implementasi PT Jaringan Persaingan Internasional (CPI / ICN) . Dalam yurisdiksi yang memiliki tinjauan dan kontrol merger, tinjauan merger menempati sebagian besar anggaran dan staf. Karena sumber daya staf yang terbatas, notifikasi merger awalnya harus - paling tidak - hanya diperlukan untuk ambang batas transaksi pertemuan yang sangat tinggi. Beberapa sarjana membaca bahasa asli dan otentik dari Pasal 28 Undang-undang Nomor 5 Tahun 1999 tentang Larangan Praktek Monopoli dan Persaingan Usaha Tidak Sehat sebagai kuasa yang memberikan KPPU kebebasan penuh untuk menafsirkan regulasi tersebut sebagai melarang semua merger dan akuisisi terlepas dari efeknya. Namun, tujuan mengkaji merger dan akuisisi adalah untuk menilai, kasus per kasus, kemungkinan dampak transaksi terhadap persaingan. Amandemen undang-undang tersebut dapat menjelaskan bahwa hanya merger atau akuisisi yang memenuhi ambang batas untuk kerugian persaingan di Indonesia yang akan dilarang atau tunduk pada persyaratan untuk pembersihan.

Terlebih daripada itu, dengan adanya kewajiban untuk melakukan notifikasi pramerger tidak menjadi suatu persoalan karena maka segala keputusan KPPU dapat diajukan ke judicial review. Hal ini dibuktikan menurut sistem hukum Indonesia, bahwa keputusan KPPU dapat diajukan banding ke pengadilan negeri. Banding keputusan pengadilan distrik harus ditinjau oleh Mahkamah Agung, melewati Pengadilan Tinggi, seperti yang disebutkan di atas. Kemudian, Mahkamah Agung mengeluarkan Perma No. 1/2003 (Peraturan Mahmakah Agung - Perma), yang merupakan instruksi yang jelas kepada pengadilan negeri tentang bagaimana 
memperlakukan keberatan (keputusan) terhadap keputusan KPPU. Dengan begitu, tidak menjadi suatu kekhawatiran untuk terjadinya penghambatan usaha karena kesalahan keputusan KPPU. Hal ini dapat dijawab dengan adanya sarana-sarana keadilan melalui judicial review bagi pelaku usaha yang keberatan dengan keputusan KPPU.

Mekanisme atau tata cara dalam melakukan pre-merger notification, tetap mengikuti ketentuan yang telah ada dalam Lampiran Peraturan Komisi Pengawas Persaingan Usaha Nomor 1 Tahun 2009 dan disesuaikan dengan beberapa pertimbangan yang nantinya diperlukan. Tata cara tersebut dapat dijabarkan sebagai berikut:

1. Pelaku usaha yang telah memiliki rencana untuk merger dan telah memenuhi batasan nilai yang telah ditetapkan oleh Komisi melakukan pra-notifikasi kepada Komisi.

2. Pelaku Usaha mengisi Formulir Pra-Notifikasi, menyampaikan dokumendokumen yang dipersyaratkan yang telah ditetapkan Komisi.

3. Komisi berhak untuk meminta tambahan dokumen kepada pelaku usaha bila diperlukan.

4. Setelah dokumen lengkap dan memenuhi syarat administrasi, Komisi mengeluarkan pernyataan dokumen lengkap dan mulai melakukan penilaian awal atas rencana penggabungan, peleburan dan atau pengambilalihan saham.

5. Dalam jangka waktu selambat-lambatnya 30 (tiga puluh) hari Komisi akan memberikan penilaian awal atas Notifikasi yang dilakukan Pelaku Usaha. Penilaian awal tersebut berupa: ada tidaknya kekhawatiran praktek monopoli dan atau persaingan usaha tidak sehat atas rencana penggabungan atau peleburan atau pengambilalihan atas dasar perubahan derajat konsentrasi pasar sebelum dan sesudah merger sesuai dengan spektrum Hirschman-Herfindahl Index (HHI).

6. Berdasarkan penilaian terhadap HHI pasca merger, maka terdapat empat tindak lanjut terhadap pra-notifikasi merger, yaitu:

a. HHI dibawah 1800 : Komisi mengeluarkan No Objection Letter.

b. HHI antara 1800 sampai dengan 3000 : Komisi melakukan penilaian menyeluruh.

c. HHI antara 3000 sampai dengan 4000 : Komisi mengeluarkan Conditional No Objection Letter.

d. HHI di atas 4000 : Komisi mengeluarkan Objection Letter.

7. Dalam hal Komisi melakukan penilaian menyeluruh terhadap rencana merger yang disampaikan Pelaku Usaha, Komisi akan mengumpulkan data-data dan informasi dari berbagai pihak seperti, pesaing, konsumen, pemerintah, dan pihak-pihak lain yang diperlukan.

8. Dalam jangka waktu selambat-lambatnya 60 (enam puluh) hari Komisi akan melakukan penilaian menyeluruh dan mengeluarkan Pendapat Awal Komisi. 
9. Terkait dengan penilaian awal ataupun Pendapat Awal Komisi berupa Objection Letter dan Conditional No Objection Letter, pelaku usaha dapat melakukan konsultasi dengan Komisi, khususnya terkait dengan alasanalasan keberatan Komisi terhadap rencana merger maupun syarat-syarat yang ditetapkan oleh Komisi atas rencana merger.

10. Dalam jangka waktu selambat-lambatnya 30 (tiga puluh) hari sejak dimulainya tahap konsultasi, Komisi akan mengeluarkan Pendapat Akhir Komisi terhadap recana merger yang disampaikan kepada pelaku usaha yang bersangkutan dan mengumumkannya sekurang-kurangnya melalui website Komisi.

11. Dalam hal Pendapat Akhir Komisi berupa Conditional No Objection Letter, Komisi akan melakukan monitoring terhadap pelaksanaan syarat-syarat merger yang ditetapkan tersebut dalam jangka waktu yang disesuaikan dengan lamanya pelaksanaan syarat-syarat tersebut serta membuat laporan dan rekomendasi selanjutnya terhadap merger tersebut kepada Komisi.

Sebagaimana penjelasan tersebut, kebijakan pre-merger notification menjadi suatu kewajiban (bukan lagi pilihan) untuk beberapa bentuk usaha tertentu yang telah sesuai dengan nilai ambang batas yang ditetapkan KPPU. Sehingga dalam penerapan reformulasi terhadap penyesuaian dengan pre-merger notification, terdapat rambu-rambu yang perlu diperhatikan sehingga dapat dijabarkan sebagai berikut:

1. Ambang batas untuk pemberitahuan wajib merger harus cukup tinggi.

2. Ambang batas tinjauan merger tidak boleh ditentukan dalam undangundang dan undang-undang harus memuat aturan di mana ambang batas tersebut dapat diadaptasi dengan mudah dan tepat waktu.

3. Kata-kata dalam Pasal 28 harus diubah untuk menetapkan bahwa merger harus ditinjau dan disahkan oleh KPPU, dengan kemungkinan bagi KPPU untuk memaksakan kondisi, menolak atau memblokir transaksi.

4. Sebagai aturan transisi, KPPU harus mengadopsi kontrol merger yang tidak wajib. Sehingga, kontrol merger yang tidak wajib dapat dibuat. Tidak semua pemberitahuan wajib, tetapi KPPU akan sepenuhnya diinvestasikan dengan wewenang untuk menyelidiki transaksi untuk pengaruhnya terhadap persaingan. Dalam hal ini, KPPU juga harus memiliki wewenang untuk memaksakan kondisi atau memblokir transaksi di Indonesia.

Melalui penjabaran tersebut maka dapat dipahami bahwa penerapan premerger notification memiliki konsekuensi yang besar jika tidak dibarengi dengan pertimbangan yang komprehensif. Karena pertumbuhan globalisasi turut berdampak pada tumbuhnya bentuk bisnis baru yang berdampak besar pada perekonomian negara. Sebagai penyeimbang dari hal tersebut maka untuk menyiapkan keadaan hukum terhadap Revolusi Industri 4.0, negara melalui KPPU harus mampu memberikan pelayanan terbaik demi terciptanya kesinambungan usaha yang sehat dalam perekonomian pasar Indonesia maupun pada perekonomian dunia yang turut berdampak pada ekonomi Indonesia. Dengan kata lain KPPU harus diberikan 
kewenangan lebih untuk dapat mejangkau subjek hukum diluar wilayah teritorial, karena menimbang bentuk usaha pada Revolusi Industri 4.0 akan mengalami perubahan bentuk yang siknifikan, dimana pelaksanaan suatu usaha dapat dilakukan dengan sistem online dan mengandalkan kecanggihan manufaktur modern. Hal ini harus dipersiapkan demi menciptakan keseimbangan usaha di waktu yang akan datang.

\section{KESIMPULAN}

Banyak praktik yang sekarang diperangi oleh UU Persaingan selama bertahuntahun. Dengan diadopsinya UU Persaingan, praktik-praktik mapan ini tiba-tiba dinyatakan ilegal. Dalam situasi ini, diharapkan masyarakat, bisnis, dan kehakiman terbiasa dengan tujuan dan konsep hukum persaingan. Kesalahpahaman seperti otoritas persaingan ada untuk memerangi bisnis besar dan melindungi, dengan cara apa pun, perusahaan kecil sangat umum. KPPU mengidentifikasi kepercayaan publik terhadap otoritas sebagai aset penting dalam menerapkan kebijakan persaingan. Untuk mempertahankan dukungan publik, dalam prioritasnya termasuk pilihan kasus yang secara langsung dan substansial bermanfaat bagi masyarakat atau konsumen.

Keberadaan KPPU menjadi suatu hal yang perlu dioptimalkan seiring dengan berjalannya perkembangan zaman. Hal ini karena objek dari KPPU sendiri merupakan kegiatan usaha pasar yang cenderung berubah-ubah mengikuti dinamika globalisasi. Kesiapan KPPU untuk mampu menciptakan keadaan pasar yang kondusif harus didukung dengan regulasi yang fleksibel dan mampu memberikan kewenangan kepada KPPU dalam menjangkau tindakan pasar tertentu karena perkembangan pasar perekonomian tidak dapat diprediksi secara pasti. Bentuk Revolusi Industri 4.0 yang merupakan tantangan bagi negara untuk dapat menyiapkan segala kebutuhan sedini mungkin, sehingga ketika sudah pada saat dimana cara kerja dunia industri mengalami perubahan menjadi penggabungan teknologi otomatisasi dengan teknologi cyber dan internet network system. Indonesia tetap mampu menjaga stabilitas perekonomian agar tidak terciptanya suatu persaingan usaha yang tidak sehat atau suatu praktik monopoli.

Kewenangan KPPU untuk dapat melakukan pengawasan lebih dini yakni dengan perubahan rezim pasca-merger notification menjadi pra-merger notification merupakan hal yang perlu dilakukan, karena hal tersebut diyakini sebagai bentuk optimalisasi yang diperlukan agar KPPU mampu memberikan pengawasan yang intensif terhadap segala bentuk pelaksanaan merger yang berdampak pada terciptanya persaingan tidak sehat. Hal tersebut tentu memberikan keuntungan bagi KPPU dan pelaku usaha, karena akan menghapus potensi untuk terjadinya pembatalan merger suatu perusahaan yang berdampak pada kerugian materiil yang tidak sedikit. Disamping hal tersebut tentu penerapan pra-merger notification harus dilakukan 
pertimbangan yang lebih maksimal dengan melihat konsekuensi yang mungkin terjadi.

\section{DAFTAR PUSTAKA}

Alison Jones dan Brendan Surfin. 2011. EU Competition Law Text. Cases. and Materials 4 th Edition. New York: Oxford University Press Inc.

Andi Fahmi Lubis et. al.. 2009. Hukum Persaingan Usaha Antara Teks dan Konteks. Jakarta: Deutsche Gesellschaft fur Technische Zusammenarbeit (GTZ) GmbH.

Andrew Dunnet. 1998. Understanding Market: An Introduction to Microeconomics. 3 rd Edition. Indiana: Longman.

International Chamber of Commerce. 2015. "ICC Recommendations On PreMerger Notification Regimes" A policy statement prepared by the ICC Commission on Competition.

Kata Data. "Merger dan Akuisisi di Indonesia 2016 Tumbuh 26\%" https://databoks.katadata.co.id/ datapublish/2017/05/15/merger-danakuisis i-indonesia-2016-tumbuh-26 diakses pada 25 Maret 2019.

Komisi Pengawasan Persaingan Usaha. Laporan Pengawasan Persaingan Usaha Tahun 2017.

Lasi (et.al). 2014. Industry 4.0.. Business \& Information Systems Engineering.

Pakpahan Normin S. 1995. Hukum Perusahaan Indonesia. Jakarta: Yayasan Pengembangan Hukum Ekonomi Indonesia.

Perdana A. Saputro. 2012. Hukum Meger Indonesia dalam Konteks Hukum Persaingan Usaha. Tangerang: CR Publishing.

R Drath \& Horch. 2014. "Industrie 4.0: Hit or hype?". Industrial Forum. IEEE Industrial Electronics Magazine.

Sudjana. 2016. "Merger Dalam Perspektif Praktik Monopoli dan Persaingan Usaha Tidak Sehat Berdasarkan UU Nomor 5 Tahun 1999”. Jurnal Hukum POSITUM. Vol. 1. No. 1. Desember.

Thee Kian Wie. 2004. "Kebijakan Persaingan dan Undang-undang Antimonopoli dan Persaingan di Indonesia." dalam buku Pembangunan. Kebebasan. dan "Mukjizat" Orde Baru. Cet 1. Jakarta: Penerbit Buku Kompas.

Weston. J. Fred. dalam Munir Fuady. 1999. Hukum Tentang Merger. Bandung:

Citra Aditya Bakti. 